\title{
АНТИПРОЛИФЕРАТИВНАЯ АКТИВНОСТЬ ДАУНОРУБИЦИНА, МОДИФИЦИРОВАННОГО ПО АТОМУ АЗОТА СЕСКВИТЕРПЕНОВЫМИ ЛАКТОНАМИ
}

\author{
А.А. Глоба, А.В. Семаков, С.А. Пухов, Л.В. Аникина, С.В. Афанасьева, \\ С.Г. Клочков
}

Лаборатория природных соединений, Институт физиологически активных веществ РАН, 142432, РФ, Черноголовка, Северный проезд, 1.

DOI: 10.19163/MedChemRussia2021-2021-368

E-mail: globa271194@mail.ru

Антрациклиновые антибиотики и сегодня остаются востребованы при лечении многих гематологических и солидных опухолей, однако их применение осложняется развитием устойчивости опухолевых клеток. Для снижения развития резистентности активно проводят модификации антрациклиновых антибиотиков природными соединениями различных классов. Нами были синтезированы конъюгаты даунорубицина по 3'-аминогруппе со следующими сесквитерпеновыми лактонами: эпоксиизоалантолактоном, телекином, изотелекином, рейнозином, костунолидом, дегидрокостуслактоном, сантамарином.

Конъюгаты были протестированы в отношении опухолевых клеточных линий Jurkat, HL-60, K562 и A549. Было оценено влияние соединений на клеточный цикл (окрашивание FxCycle) и на индукцию апоптоза/некроза (окрашивание Annexin V и SYTOX Blue) в дозах, равных IC ${ }_{50}$ даунорубицина, при 24 и 48 часах инкубации с помощью проточной цитофлуориметрии. Для соединений с наиболее близкими к даунорубицину эффектами, проведена оценка состояния актиновых филаментов (окрашивание Rhodamine phalloidin) на культуре A549 при 24 часов инкубации в дозе, сравнимой с IC 50 даунорубицина, методом флуоресцентной микроскопии.

В выбранной дозе все соединения сохраняют сходное с даунорубицином накопления клеток в G2/M фазе клеточного цикла. Кроме того, конъюгаты, как и исходный антибиотик, обладают слабым влиянием на запуск апоптоза. Наиболее близкие к даунорубицину эффекты проявляют конъюгаты с дегидрокостуслактоном и эпоксиизоалантолактоном.

При оценке влияния соединений на состояние актина было установлено увеличение числа многоядерных клеток с нарушенной структурой актиновых филаментов (актиновые волокна не собираются или собираются неправильно, приводя к ремоделированию), как и при обработке даунорубицином.

Полученные данные свидетельствуют о том, что основной эффект исследуемых конъюгатов - цитостатический, который, вероятно, реализуется через влияние на сборку актиновых филаментов, участвующих в процессе деления клеток. 